ARTICLE

\title{
Nickel-catalyzed electrochemical carboxylation of unactivated aryl and alkyl halides with $\mathrm{CO}_{2}$
}

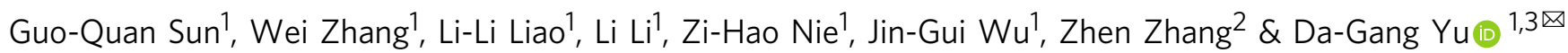

Electrochemical catalytic reductive cross couplings are powerful and sustainable methods to construct $\mathrm{C}-\mathrm{C}$ bonds by using electron as the clean reductant. However, activated substrates are used in most cases. Herein, we report a general and practical electro-reductive $\mathrm{Ni}$ catalytic system, realizing the electrocatalytic carboxylation of unactivated aryl chlorides and alkyl bromides with $\mathrm{CO}_{2}$. A variety of unactivated aryl bromides, iodides and sulfonates can also undergo such a reaction smoothly. Notably, we also realize the catalytic electrochemical carboxylation of aryl (pseudo)halides with $\mathrm{CO}_{2}$ avoiding the use of sacrificial electrodes. Moreover, this sustainable and economic strategy with electron as the clean reductant features mild conditions, inexpensive catalyst, safe and cheap electrodes, good functional group tolerance and broad substrate scope. Mechanistic investigations indicate that the reaction might proceed via oxidative addition of aryl halides to $\mathrm{Ni}(0)$ complex, the reduction of aryl-Ni(II) adduct to the $\mathrm{Ni}(\mathrm{I})$ species and following carboxylation with $\mathrm{CO}_{2}$.

\footnotetext{
${ }^{1}$ Key Laboratory of Green Chemistry \& Technology of Ministry of Education, College of Chemistry, Sichuan University, Chengdu 610064, China. ${ }^{2}$ College of Pharmacy and Biological Engineering, Chengdu University, Chengdu 610041, China. ${ }^{3}$ Beijing National Laboratory for Molecular Sciences, Beijing 100190, P. R. China. ${ }_{\text {email: dgyu@scu.edu.cn }}$
} 
$\mathrm{R}$ eductive cross couplings represent powerful methods to generate $\mathrm{C}-\mathrm{C}$ bonds by circumventing extra synthetic steps and handling moisture-sensitive organometallic reagents ${ }^{1}$. Much progress has been achieved in last decades via transition metal catalysis ${ }^{2,3}$ and photocatalysis ${ }^{4}$. Recently, significant advance of electrochemistry ${ }^{5-20}$ has attracted much attention with electron as clean reductant, providing a sustainable solution for chemical synthesis ${ }^{5,6}$. Compared to direct electrochemistry, electrocatalysis is more attractive and useful due to the lower potential and better functional group tolerance ${ }^{11-14}$. Notably, electrochemical transition metal-catalysis ${ }^{15-20}$, especially $\mathrm{Ni}$-catalysis ${ }^{20}$, is efficient and powerful in reductive cross couplings. Electro-reductive Ni-catalyzed coupling of aryl halides with organo (pseudo)halides ${ }^{21}$ and carbonyl-containing compounds $^{22}$ has emerged as a convenient strategy. However, most of such cases are limited to activated aryl halides, which bear electron-withdrawing groups (EWGs) or electron-poor heteroarenes. The electrocatalytic reductive cross couplings of unactivated aryl halides, especially unactivated aryl chlorides, are challenging tasks to resolve ${ }^{23}$.

Carboxylation of organohalides with $\mathrm{CO}_{2}$ is a direct and effective way to construct valuable carboxylic acids (Fig. 1a) due to the abundant, nontoxic and recyclable properties of $\mathrm{CO}_{2}{ }^{24-30}$. However, the thermodynamic stability and kinetic inertness make it difficult to achieve high efficiency under mild reaction conditions. It is even more challenging when the inexpensive coupling partners are less reactive. Although recent progress has shown some robust catalytic manners in transition-metal catalysis ${ }^{31,32}$

a
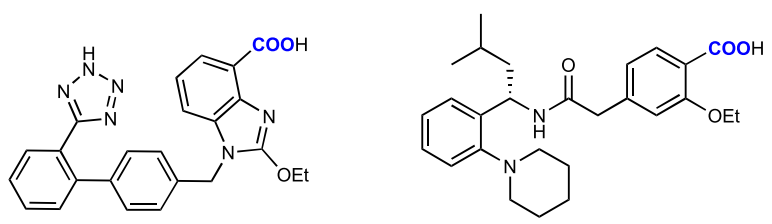

Blopress

Prandin

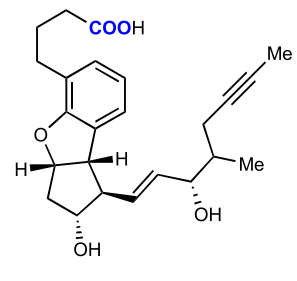

Beraprost
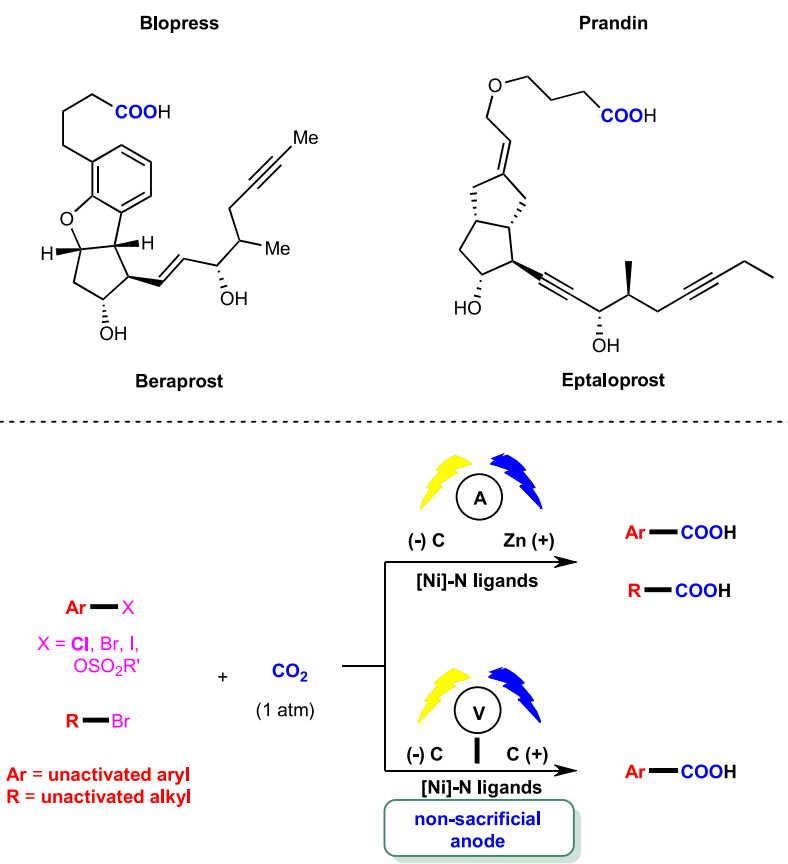

(+) Electrocatalytic carboxylation of unactivated aryl chlorides and alkyl bromides

$(+)$ The use of non-sacrificial anode in electrocatalytic carboxylation

$(+)$ Inexpensive $\mathrm{Ni}$-catalyst and mixed nitrogen ligands

(+) Good functional group tolerance and broad substrate scope

Fig. 1 Background and synopsis of our work. a Selected examples of bioactive compounds containing carboxylic acid moiety. b A general electrocatalytic carboxylation of unactivated organo (pseudo)halides with $\mathrm{CO}_{2}$. and photocatalysis ${ }^{33-38}$, the use of stoichiometric amount of extra metallic reductants, expensive Ir-photosensitizer, or reactive organohalides still limites their wide application. Meanwhile, electrocatalytic carboxylation of activated aryl (pseudo) halides $22,39-44$, benzylic and allylic ones ${ }^{45}$ have been investigated. However, selective electrocatalytic carboxylation of unactivated aryl chlorides and unactivated alkyl halides with $\mathrm{CO}_{2}$ have rarely been realized ${ }^{46-50}$, which are more challenging due to the low reactivity of both unactivated organohalides and $\mathrm{CO}_{2}$ as well as many competing side reactions, such as protonation, $\beta-\mathrm{H}$ elimination, migration, and homodimerization of the generated organometallic reagents and electrochemical decarboxylation of the products ${ }^{51}$. Besides the limitations in substrate scope, the reductive electrochemical carboxylations mainly rely on the use of sacrificial electrodes ${ }^{52-56}$.

Here, we show a general and practical electrochemical Nicatalytic system, realizing the electrocatalytic carboxylation of challenging aryl chlorides and unactivated alkyl bromides with $\mathrm{CO}_{2}$ (Fig. 1b). A variety of unactivated aryl bromides, iodides, and sulfonates also undergo such a reaction smoothly. Moreover, the catalytic electrochemical carboxylation of aryl (pseudo)halides with $\mathrm{CO}_{2}$ avoiding the use of sacrificial electrodes is also developed.

\section{Results}

Optimization of Ni-catalyzed electrochemical carboxylation. We initiated our studies by exploring electro-reductive Ni-catalytic carboxylation of 4-chlorobiphenyl 1a with $\mathrm{CO}_{2}$ (see Supplementary Table 1). Considering that aryl chlorides are less reactive than aryl bromides or iodides, we proposed that a highly reactive $\mathrm{Ni}$-catalytic system should be developed to improve the challenging oxidative addition under mild reaction conditions. We decided to explore proper ligand to keep the Ni-catalyst active and increase the catalytic efficiency. After systematic condition screening, we were delighted to realize the carboxylation of $\mathbf{1 a}$ to give $2 \mathbf{a}$ in $70 \%$ yield in the undivided cell by using Ni-catalyst and mixed nitrogen ligands, which contained ditertbutylbipyridine $(\mathrm{L}$, dtbbpy) and 4-dimethylaminopyridine (DMAP) (Supplementary Table 1, entry 1). Both of these two ligands were important as no or low efficiency was observed in the absence of either one (Supplementary Table 1, entries 2 and 3). Besides, Lewis acidic $\mathrm{MgBr}_{2}$ also promoted the reaction (Supplementary Table 1, entry 4), which might coordinate with $\mathrm{CO}_{2}$ and increase its electrophilicity ${ }^{57,58}$. Control experiments verified the essential role of nickel catalyst, $\mathrm{CO}_{2}$, and electricity (Supplementary Table 1, entries 5-7). The use of potassium tert-butoxide $\left(\mathrm{KO}^{t} \mathrm{Bu}\right)$ had improvement for the carboxylation (Supplementary Table 1, entry 8). Supporting electrolyte also had a significant effect on the reaction (Supplementary Table 1, entry 9). Varying from other parameters, such as solvent and electric current, did not give better results (Supplementary Table 1, entries 10-12).

Substrate scope. With the optimal reaction conditions in hand, we first explored the scope of aryl chlorides (Fig. 2). A variety of unactivated aryl chlorides underwent the carboxylation smoothly to give the desired acids in moderate to good yields (1a-1f). Notably, the substrate 1c bearing free alcohol, which might undergo oxidation via $\beta-\mathrm{H}$ elimination ${ }^{59}$ or coupling via $\mathrm{C}-\mathrm{O}$ bond activation ${ }^{60}$, was not reported in previous carboxylations with $\mathrm{CO}_{2}{ }^{31,33}$. Deactivated aryl chlorides (1e and 1f) bearing with electron-donating groups (EDGs) at the para position, which show no or lower reactivity in previous carboxylations ${ }^{31-38}$, were also amenable to our reaction. Notably, clofibrate (1f), a commercially available drug, underwent the reaction to afford $2 \mathbf{f}$ in $53 \%$ yield, which might be applied in drug discovery to improve 


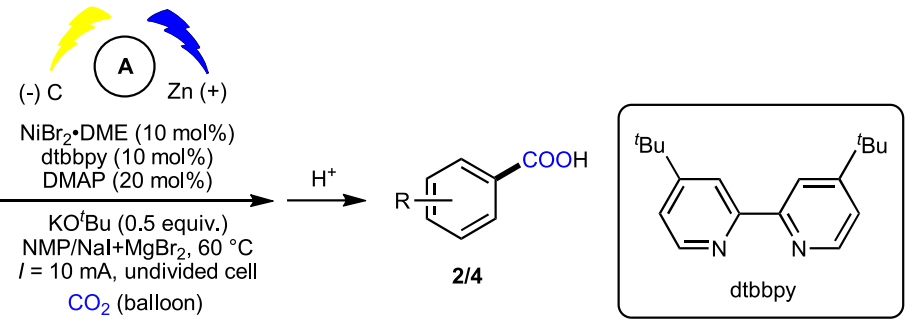

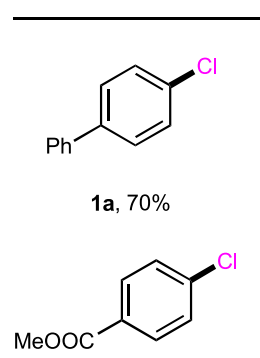

1g, $70 \%$ d,e

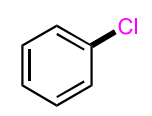

1b, $62 \%$<smiles>Clc1ccc(Cl)cc1</smiles>

1h, $50 \%$ d,f

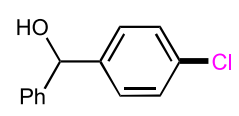

1c, $52 \%^{\mathrm{b}}$ aryl chlorides $^{a}$<smiles>CC(=O)c1cccc(Cl)c1</smiles>

1i, $74 \%$<smiles>Fc1ccc(Cl)cc1</smiles>

1d, $67 \%$<smiles>COc1ccc(Cl)cc1</smiles>

1 e, $52 \%$<smiles>CCOC(=O)C(C)(C)Oc1ccc(Cl)cc1</smiles>

1f, $53 \%^{\mathrm{c}}$

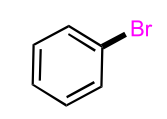

3a, $74 \%, 24 \mathrm{~h}$<smiles>Fc1ccc(Br)cc1</smiles>

$3 g, 54 \%, 4 h^{d}$<smiles>COC(OC)c1cccc(Br)c1</smiles>

$3 \mathrm{~m}, 87 \%, 8 \mathrm{~h}^{\mathrm{d}, \mathrm{g}}$<smiles>Brc1ccc2oc3ccccc3c2c1</smiles>

3s, $84 \%, 19 \mathrm{~h}$<smiles>[O-]c1cccc2ccccc12</smiles>

3y, $79 \%, 7 h^{d}$<smiles>Brc1ccc(-c2ccccc2)cc1</smiles>

3b, $84 \%, 12 \mathrm{~h}$<smiles>CCOC(=O)c1ccc(Br)cc1</smiles>

$3 h, 86 \%, 4 h^{d}$<smiles>Brc1ccccc1-c1ccccc1</smiles>

$3 n, 57 \%, 24 h^{d, e}$<smiles>CC(C)(C)Oc1ccc(Br)cc1-n1c2ccccc2c2ccccc21</smiles>

3t, $43 \%, 12 h^{d}$<smiles>COc1ccc([Se-])cc1</smiles>

$3 z, 78 \%, 24 h^{d, h}$ aryl bromides, iodines and sulfonates<smiles>COc1ccc(Br)cc1</smiles>

$3 c, 73 \%, 12 \mathrm{~h}$<smiles>Cc1cccc(Br)c1</smiles>

3i, $91 \%, 4 \mathrm{~h}$<smiles>Brc1cc(-c2ccccc2)cc(-c2ccccc2)c1</smiles>

3o, $72 \%, 6 \mathrm{~h}^{\mathrm{d}}$<smiles>Ic1ccc(-c2ccccc2)cc1</smiles>

$3 u, 80 \%, 8 h^{d}$<smiles>COc1ccc(O)cc1</smiles>

3aa, $71 \%, 12 \mathrm{~h}$<smiles>POc1ccc(Br)cc1</smiles>

3d, $80 \%, 12 \mathrm{~h}^{\mathrm{d}}$<smiles>COc1cccc(Br)c1</smiles>

3j, $81 \%, 12$ h<smiles>Clc1ccc2ccccc2c1</smiles>

1k, $75 \%$<smiles>Clc1cccc2ccccc12</smiles>

1I, $74 \%$

Fig. 2 Scope of aryl chlorides, bromides, iodines, and sulfonates. "Reaction conditions, see more details in "Supplementary information". b5 $\AA$ molecular sieve was added. ${ }^{\mathrm{CNiBr}}{ }_{2} \bullet \mathrm{DME}(5 \mathrm{~mol} \%)$, dtbbpy (5 mol\%), DMAP (10 mol\%). d Ni(acac) 2 (5 mol\%), dtbbpy (5 mol\%), KOtBu (0.5 equiv), I= $8 \mathrm{~mA}$.

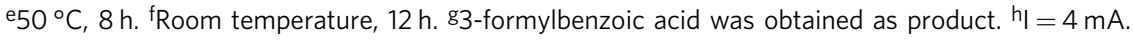

the hydrophilicity and metabolism of drug molecules. As electron-deficient aryl chlorides were more reactive coupling partners, they could take part in the reaction with lower catalyst loading and temperature in the absence of either DMAP or $\mathrm{MgBr}_{2}$. Notably, this electrochemical approach exhibited good tolerance to diverse functional groups, including hydroxyl (1c), fluoro (1d), methoxyl (1e), ester (1f, $\mathbf{1 g}$, and $\mathbf{1 i})$, and ketone (1h and $\mathbf{1 j}$ ). Besides substituted phenyl chlorides, 2-naphthyl and more sterically hindered 1-naphthyl chlorides were also suitable substrates in our reaction. The substrates with more steric hindrance, such as 2-methylphenyl chloride, were unreactive in our case, which might arise from more difficult oxidative addition of $\mathrm{C}-\mathrm{Cl}$ bonds.

We further examined carboxylation of other unactivated aryl (pseudo)halides (Fig. 2). Besides simple phenyl bromide 3a, a broad range of para- and meta-substituted aryl bromides $(3 \mathbf{b}-3 \mathbf{m})$ reacted well with $\mathrm{CO}_{2}$ to afford the desired carboxylic acids in good yields. Interestingly, the sterically hindered aryl 


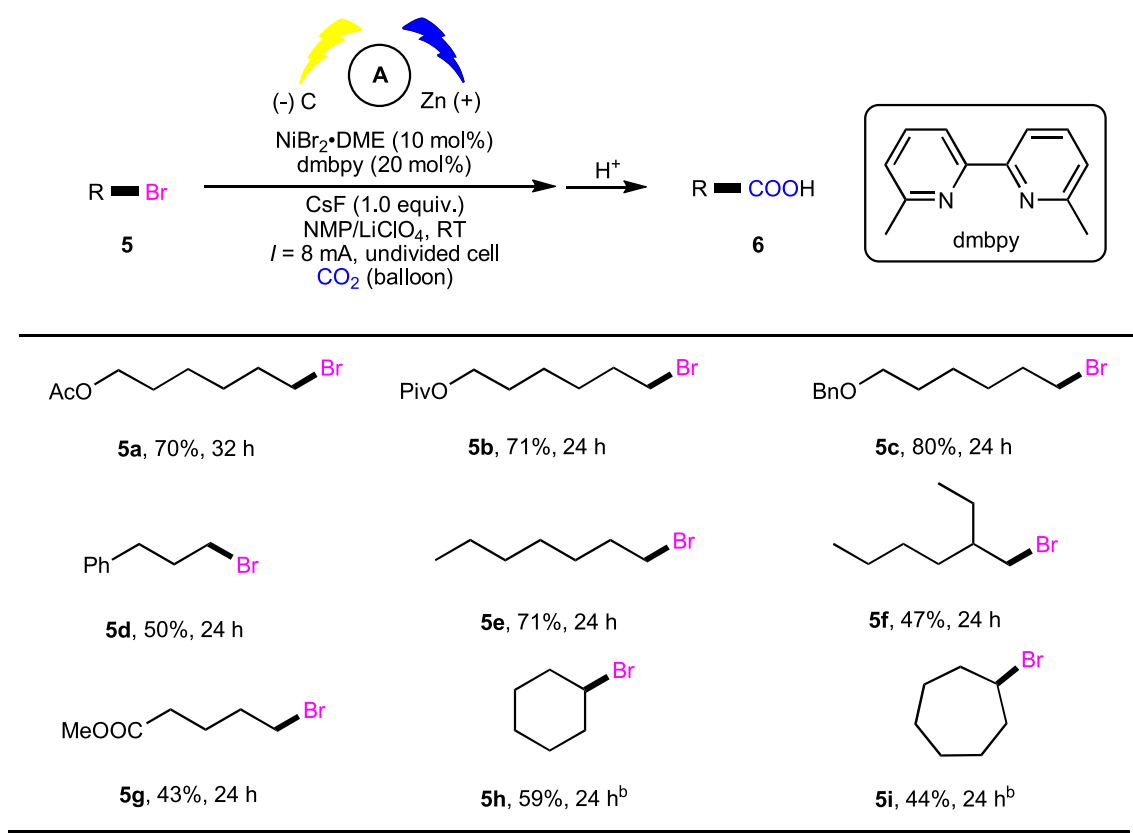

Fig. 3 Scope of alkyl bromides. aReaction conditions, see more details in "Supplementary information". bl $=4 \mathrm{~mA}$.

bromide 3n bearing ortho phenyl group could also undergo the carboxylation in moderate efficiency. Moreover, the carboxylation of di-substituted phenyl (3o, 3p) and fused (hetero)aryl bromides (3r-3t) was also smooth. Deactivated aryl bromides (3c, 3e, 3j, $3 \mathbf{k}, \mathbf{3 p}-\mathbf{3 t}$ ) bearing EDGs were also reactive in this process to give desired carboxylic acids in good yields. A set of functional groups, such as ether (3c, 3d, 3j, 3k, 3p), thioether (3e), hydroxyl (3f), fluoro $(\mathbf{3 g})$, ester $(\mathbf{3 h})$, alkene (3l), acetal (3m) and heterocycles $(\mathbf{3 r}-\mathbf{3 t})$, were well tolerated. Besides aryl bromides, aryl iodides $(\mathbf{3 u}-\mathbf{3 w})$ also underwent the carboxylation smoothly. Moreover, aryl sulfonates $(\mathbf{3} \mathbf{x}-\mathbf{3} \mathbf{a b})$, such as a mesylate, tosylates, and triflates, which are easily available from phenols, also showed high reactivity and selectivity in this reaction.

Furthermore, we investigated more challenging carboxylation of unactivated alkyl bromides to give important alkyl carboxylic acids. To our delight, a range of primary alkyl bromides (5a-5g) could afford the corresponding carboxylic acids in moderate to good yields with good functional group tolerance under slightly modified conditions (Fig. 3). Moreover, unactivated cyclic alkyl bromides (5h and $\mathbf{5 i}$ ) could also take part in this reaction to generate carboxylic acids with synthetically useful yields, although these substrates were considered as challenging coupling partners in carboxylation events ${ }^{45,46}$.

Exploration of the electrochemical carboxylation without sacrificial anode. Although electrocatalytic carboxylation of organo (pseudo) halides shows advantage to those with highly reactive metallic powders by using user-friendly and stable anodes, it would be more appealing and practical to achieve such carboxylation without using sacrificial electrodes ${ }^{52-56}$. Therefore, we further challenged us with development of an active electrocatalytic system with paired cells. After systematic investigation (see Supplementary Table 2), we were delighted to realize the catalytic electrochemical carboxylation of aryl bromide $\mathbf{3 b}$ with $\mathrm{CO}_{2}$ avoiding the use of sacrificial electrodes in $70 \%$ isolated yield. Control experiments verified that the pair anodic oxidation was essential, and the electro-oxidative chlorination of toluene ${ }^{61}$ matched well with the desired $\mathrm{Ni}$-catalyzed reductive carboxylation. Other common anodic oxidations, including the electrooxidation of triethylamine and triethanolamine (Supplementary
Table 2, entries 8-9) gave lower yields. Using this system, we found that a variety of unactivated aryl(hetero) bromides, tosylates, mesylates, and triflates worked well to give the desired carboxylic acids in satisfying yields (Fig. 4, 3a-3ae (selective examples)). Unactivated aryl chlorides (1a-1m, selective examples) also took part in this reaction well under modified conditions with the paired oxidation of triethylamine. More challenging alkyl bromides/sulfonates (5b, 5c, 5j) were also investigated, however, low reactivity was observed.

Mechanistic studies. To gain more insight into the reaction mechanism, we first applied the synthesized complex $\mathrm{LNi}(\mathrm{acac})_{2}$ as pre-catalyst in the carboxylation of $\mathbf{3} \mathbf{h}$ (Fig. 5a), which provided $\mathbf{4 h}$ in a similar yield to that of standard reaction and higher than that obtained with $\mathrm{Ni}(\mathrm{COD})_{2}$ and dtbbpy (Fig. 5b). Moreover, we carried out the stoichiometric reaction of 3ac with $\mathrm{Ni}$ catalyst to generate an oxidative addition adduct 1-1 (Fig. 5c), which showed similar catalytic activity (Fig. 5d), indicating that 1-1 might be the key intermediate in the catalytic cycle. In addition, the complex 1-2 [ArNi(dtbbpy)(DMAP)Cl] was detected in the catalytic reaction (Fig. 5e).

Furthermore, we also tested electrochemical analysis and UVvis spectroscopy (Fig. 6). We found that both the cyclic voltammogram $(\mathrm{CV})$ and absorption spectra of $\mathrm{LNi}(\mathrm{acac})_{2}$ were almost consistent with the mixture of $\mathrm{Ni}(\mathrm{acac})_{2}$ and dtbbpy in NMP solution (Fig. 6a, b), suggesting that pre-catalyst $\mathrm{LNi}(\mathrm{acac})_{2}$ was formed in situ by mixing $\mathrm{Ni}(\mathrm{acac})_{2}$ and dtbbpy by a ratio of 1:1 in NMP solution. All these results indicated that the coordination occurred between nickel catalyst and ligand. Besides, such nickel catalytic systems had two irreversible reductive peaks in the $\mathrm{CV}$ tests (Fig. 6a), which indicated that the nickel catalysts could be reduced into $\mathrm{Ni}(\mathrm{I})$ and $\mathrm{Ni}(0)$ species on the cathodic surface.

We continued to conduct $\mathrm{CV}$ tests for $\mathrm{Ni}(\mathrm{acac})_{2}$ and dtbbpy in the presence of $\mathbf{3} \mathbf{h}$ (Fig. 7a) and found a steep reductive peak at $-2.73 \mathrm{~V}\left(\mathrm{E}_{\mathrm{p}}\right)$, which indicated a typical catalytic current. Similarly strong catalytic current could also be observed when $\mathrm{LNi}(\mathrm{acac})_{2}$ was used in place of $\mathrm{Ni}(\mathrm{acac})_{2}$ and dtbbpy. Since the pre-formed nickel complex could be reduced into its $\mathrm{Ni}(0)$ form according to cyclic voltammetric results, we inferred that the 
Cathodic chamber

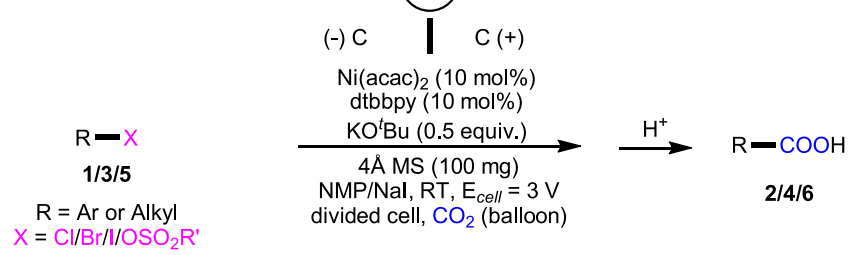

Anodic chamber: toluene (2 equiv.), NMP/LiCl.<smiles>Brc1ccccc1</smiles>

$3 a, 83 \%, 24 \mathrm{~h}^{\mathrm{b}}$<smiles>Brc1ccc(-c2ccccc2)cc1</smiles>

3b, $70 \%, 24 \mathrm{~h}$<smiles>Brc1ccc(Oc2ccccc2)cc1</smiles>

3d, $84 \%, 22 \mathrm{~h}$<smiles>Cc1ccc(Br)cc1</smiles>

$3 e, 66 \%, 36 \mathrm{~h}$<smiles>OCc1ccc(Br)cc1</smiles>

3f, $75 \%, 23 \mathrm{~h}$<smiles>COc1cccc(Br)c1</smiles>

3j, $77 \%, 24 \mathrm{~h}$<smiles>Brc1cccc(OCc2ccccc2)c1</smiles><smiles>Brc1ccccc1-c1ccccc1</smiles>

3k, $70 \%, 24 \mathrm{~h}$<smiles>Brc1cc(Br)cc(-c2ccccc2)c1</smiles>

3o, $83 \%, 20 \mathrm{~h}$<smiles>Brc1ccc2c(c1)OCO2</smiles>

$3 p, 83 \%, 22$ h<smiles>COc1ccc2cc(Br)ccc2c1</smiles>

$3 q, 50 \%, 23 \mathrm{~h}$<smiles>Brc1ccc2sc3ccccc3c2c1</smiles>

$3 r, 77 \%, 23 \mathrm{~h}$<smiles>Brc1ccc2oc3ccccc3c2c1</smiles><smiles>COc1ccc2ccccc2c1</smiles><smiles>[Se-]c1cccc2ccccc12</smiles><smiles>COc1ccc(O)cc1</smiles><smiles>C[C@]12CCC3c4ccc(Br)cc4CC[C@]3(C1)C1CCC(=O)C12</smiles><smiles></smiles>

3ab, $82 \%, 24$ h

3s, $89 \%, 22 \mathrm{~h}$

$3 x, 74 \%, 24 \mathrm{~h}$

3y, $90 \%, 24 \mathrm{~h}$

3aa, $77 \%, 22 \mathrm{~h}$<smiles>COc1ccc(Cl)cc1</smiles>

3ac, $70 \%, 24 \mathrm{~h}$<smiles>Clc1ccc(-c2ccccc2)cc1</smiles>

$1 \mathrm{a}, 61 \%, 28 \mathrm{~h}^{\mathrm{c}, \mathrm{d}}$<smiles>OC(c1ccccc1)c1ccc(Cl)cc1</smiles>

1c, $56 \%, 36 \mathrm{~h}^{\mathrm{c}, \mathrm{d}}$

$1 e, 52 \%, 28 h^{c, d}$

1f, $50 \%, 36 \mathrm{~h}^{\mathrm{c}, \mathrm{d}}$<smiles>O=C(Nc1ccc(Cl)cc1)c1cccc(Cl)c1</smiles>

1g, $70 \%, 24 \mathrm{~h}^{\mathrm{e}}$<smiles>Clc1cccc2ccccc12</smiles><smiles>FC(F)(F)c1ccc(Cl)cc1</smiles>

1I, $64 \%, 24 \mathrm{~h}^{\mathrm{c}, \mathrm{d}}$<smiles>BrCCCCCCCOc1ccccc1</smiles>

5b, $27 \%, 24 h^{\text {b, } f}$

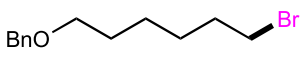

5c, $16 \%, 24 \mathrm{~h}^{\mathrm{b}, \mathrm{f}}$
$\widehat{\Upsilon O}_{\mathrm{OTS}}$

$5 j, 45 \%, 24 h^{b, f}$

Fig. 4 Scope of organo(pseudo) halides in non-sacrificial electrode manner. aReaction conditions, see more details in Table S2 in "Supplementary information". b $0.5 \mathrm{mmol}$ scale. ${ }^{\mathrm{C}} 60^{\circ} \mathrm{C}$. ${ }^{\mathrm{d}} \mathrm{Nil}_{2}$ (10 mol\%), dtbbpy (10 mol\%), DMAP (20 mol\%), $\mathrm{MgBr}_{2}$ (1.5 equiv). Anodic chamber: Et ${ }_{3} \mathrm{~N}(0.6 \mathrm{mmol}), 3 \AA$ MS (100 mg), NMP/Nal (0.2 M). e DMAP (20 mol\%) was added. ${ }^{\mathrm{f}} \mathrm{NiBr}_{2} \bullet \mathrm{DME}(10 \mathrm{~mol} \%), \mathrm{dmbby}(20 \mathrm{~mol} \%), \mathrm{CsF}(1.0 \mathrm{quiv}$.), NMP/LiClO 4 (0.2 M), RT. Anodic chamber: $\mathrm{Et}_{3} \mathrm{~N}(0.6 \mathrm{mmol}), \mathrm{NMP} / \mathrm{LiClO}_{4}(0.2 \mathrm{M}) . \mathrm{MS}=$ molecule sieve.

responsive catalytic current was attributed to oxidative addition between $\mathbf{3 h}$ and $\mathrm{Ni}(0)$ complex. After the introduction of $\mathrm{CO}_{2}$, the reductive peak current was further increased, indicating the carboxylation reaction occurred. Besides, the deactivated aryl bromide $3 \mathbf{b}$, which is reduced at $-2.64 \mathrm{~V}\left(\mathrm{E}_{\mathrm{p}}\right)$, showed the rise of its peak current in the Ni-catalytic system along with DMAP (Fig. 7b), suggesting that DMAP improved the Ni-catalytic efficiency in activating inert aryl bromide to reaction with nickel catalyst. CV test of adduct 1-1 was also investigated in NMP solution to show two irreversible reductive peaks, which might correspond to the reduction of adduct 1-1 at the cathodic surface (Fig. 7c) ${ }^{62}$. Furthermore, two new reductive peaks at $-1.86 \mathrm{~V}\left(\mathrm{E}_{\mathrm{p}}\right)$ and $-2.27 \mathrm{~V}\left(\mathrm{E}_{\mathrm{p}}\right)$ were emerged when adduct 1-1 was present in the $\mathrm{CO}_{2}$ atmosphere, which might indicate that oxidative addition complex $\mathbf{1 - 1}$ was reduced into its $\mathrm{Ni}(\mathrm{I})$ species, which then underwent carboxylation with $\mathrm{CO}_{2}$ and was further reduced into $\mathrm{Ni}(0)$ species $^{63}$. All of the results indicated that adduct 1-1 was generated during the electrolytic process and then reduced to $\mathrm{Ni}(\mathrm{I})$ species which underwent carboxylation with $\mathrm{CO}_{2}$.

Based on these results and the previous work ${ }^{15-20,31-38,64}$, a possible catalytic cycle was proposed (Fig. 8). First, the $\mathrm{L}^{\prime \prime} \mathrm{Ni}(0)$ 


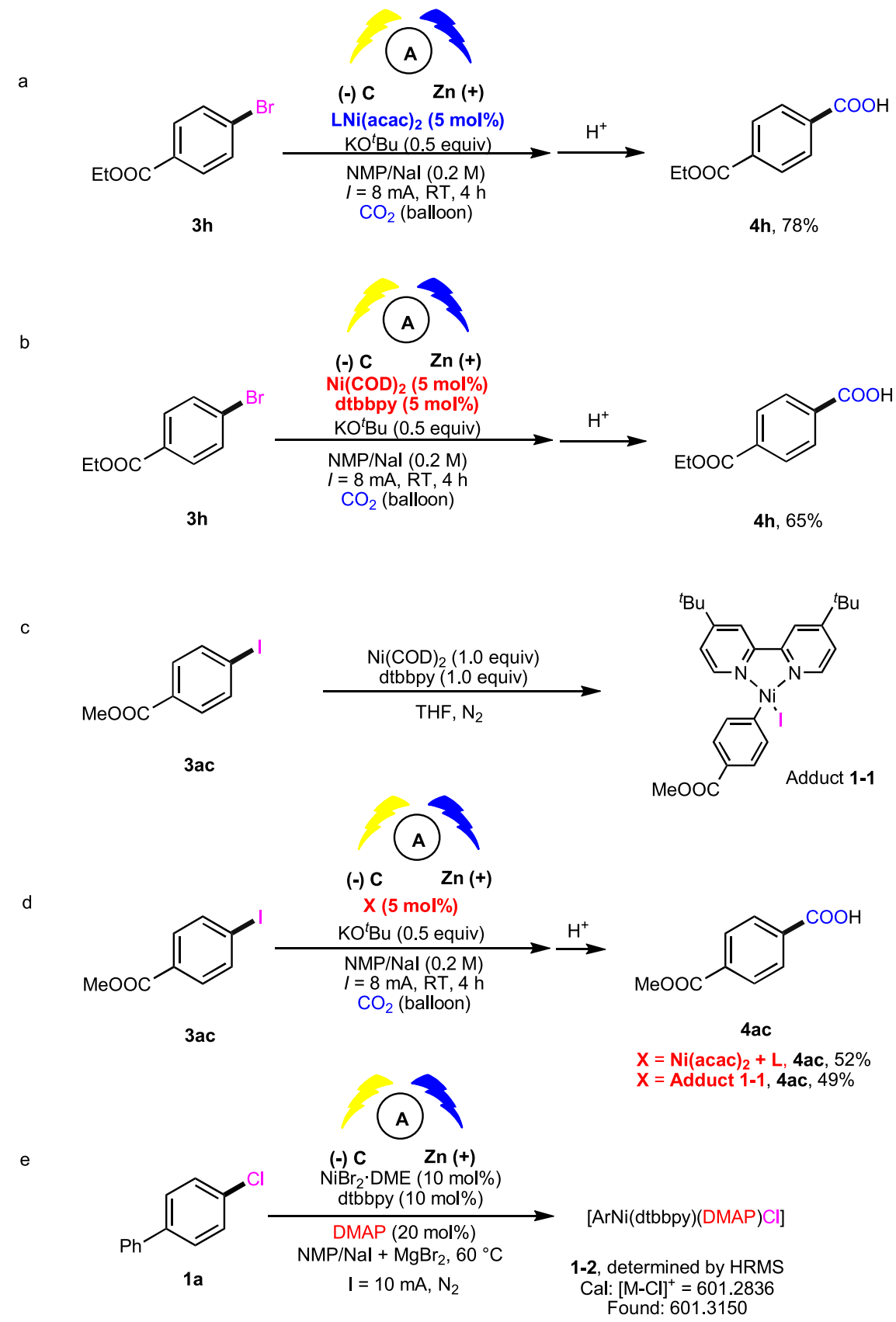

Fig. 5 Control experiments. a Investigation of the effect of nickel complex $\mathrm{LNi}(\mathrm{acac})_{2}$. b Investigation of the effect of $\mathrm{Ni}(0)$ catalyst. c Preparation of oxidative addition adduct 1-1. d Investigation of the effect of adduct 1-1. e HRMS detection of oxidation addition adduct. L $=$ dtbbpy. DMAP $=N, N$ dimethyl-4-aminopyridine. HRMS $=$ High resolution mas spectrometry.

species $\mathbf{A}$ is generated from the complex $\mathrm{Ni}(\mathrm{acac})_{2}$ in the presence of bipyridine ligand and DMAP on the cathode. Then the oxidative addition between $\mathbf{A}$ and the aryl halide occurred to yield the adduct $\mathbf{B}$, which would be further reduced to $\mathrm{Ni}(\mathrm{I})$ species $\mathbf{C}$ by cathode. Then, $\mathrm{C}$ reacted with $\mathrm{CO}_{2}$ to give the nickel carboxylate intermediate $\mathbf{D}$. Following ligand exchange and reduction of nickel carboxylate complex regenerated the active $\mathrm{Ni}(0)$-catalyst $\mathbf{A}$ and afforded carboxylate, which would undergo protonation to give the desired product.

\section{Discussion}

In this work, we have developed a general and practical electroreductive $\mathrm{Ni}$-catalytic system, realizing the electrocatalytic carboxylation of challenging, unactivated aryl chlorides and alkyl bromides with $\mathrm{CO}_{2}$. Unactivated aryl bromides, iodides, and sulfonates can also undergo such an electrocatalytic carboxylation smoothly. The use of DMAP as additional ligand and $\mathrm{MgBr}_{2}$ as Lewis acid improved the efficiency for the electrocarboxylation of unactivated aryl halides. Notably, we also realize the catalytic electrochemical carboxylation of aryl (pseudo) halides with $\mathrm{CO}_{2}$ avoiding the use of sacrificial electrodes. This protocol is operationally simple and robust with mild conditions, undivided cell, safe and cheap electrodes, good functional group tolerance, and broad substrate scope. Mechanistic investigations indicate that the reaction might proceed via oxidative addition of aryl halides to $\mathrm{L}_{\mathrm{n}} \mathrm{Ni}(0)$, further reduction to the $\mathrm{Ni}(\mathrm{I})$ species, and following carboxylation with $\mathrm{CO}_{2}$. More application 

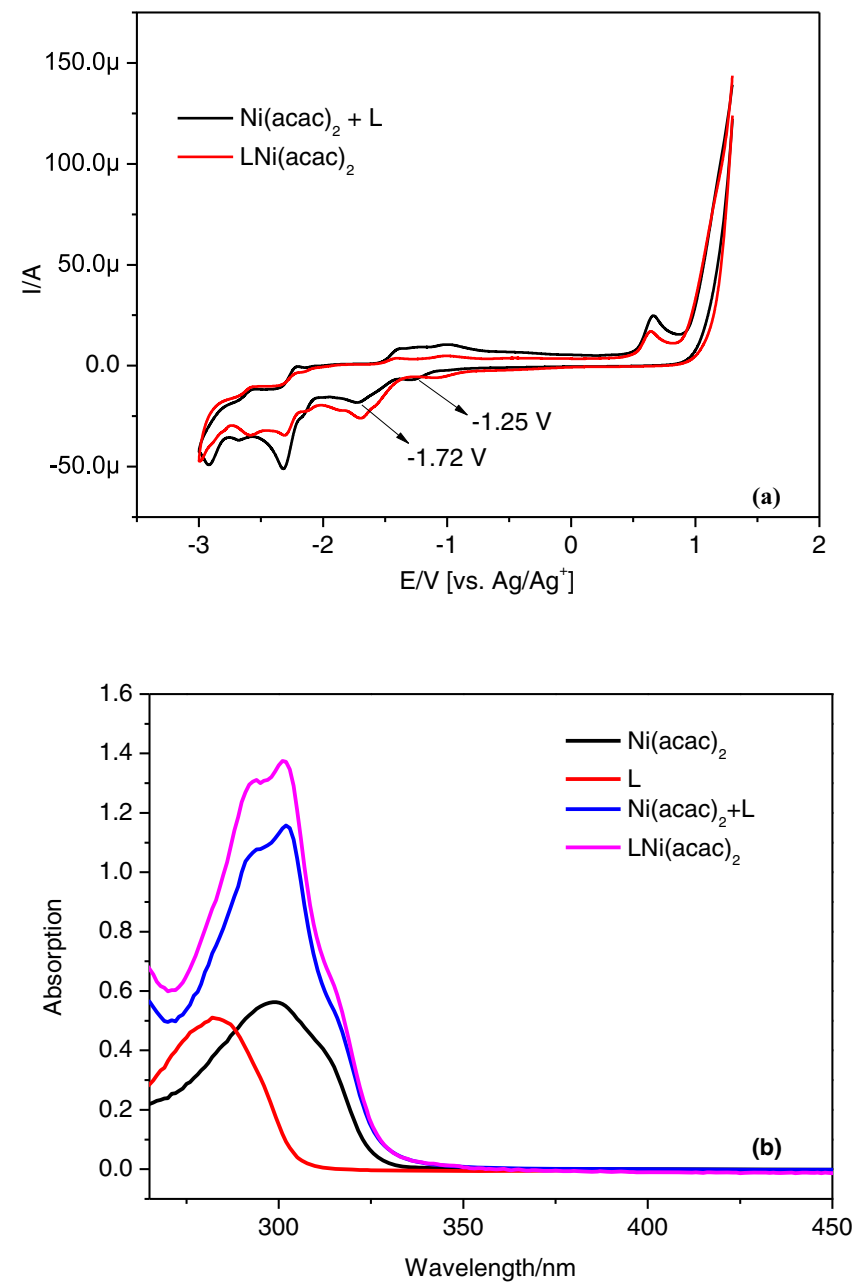

Fig. 6 Electrochemical and spectroscopic investigations. a CV tests of $\left[\mathrm{Ni}(\mathrm{acac})_{2}+\mathrm{L}\right]$ and $\mathrm{LNi}(\mathrm{acac})_{2}$. Testing conditions: working electrode, glassy carbon electrode; counter electrode, $\mathrm{Pt}$ wire; reference electrode, $\mathrm{Ag} / \mathrm{AgNO}_{3}$ electrode $\left(10 \mathrm{mM} \mathrm{AgNO}_{3}\right.$ in $\left.\mathrm{CH}_{3} \mathrm{CN}\right)$. Scan rate: $100 \mathrm{mV} / \mathrm{s}$. Solvent: $\mathrm{NMP} /{ }^{n} \mathrm{Bu}_{4} \mathrm{NPF}_{6}(0.1 \mathrm{M})$. Samples were tested under $\mathrm{N}_{2}$ atmosphere. Ni(acac) $2,3 \mathrm{mM}$; L, dtbbpy, $3 \mathrm{mM}$, LNi(acac) $2,3 \mathrm{mM}$. b UVvis spectra of $\mathrm{Ni}(\mathrm{acac})_{2}, 3 \times 10^{-5} \mathrm{M} ; \mathrm{L}, 3 \times 10^{-5} \mathrm{M} ;\left[\mathrm{Ni}(\mathrm{acac})_{2}+\mathrm{L}\right]$, $3 \times 10^{-5} \mathrm{M}+3 \times 10^{-5} \mathrm{M}$ and $\mathrm{LNi}(\mathrm{acac})_{2}, 3 \times 10^{-5} \mathrm{M}$. NMP is chosen as the testing solvent. $L=d t b b p y, 4,4^{\prime}$-di-tert-butyl-2,2'-bipyridine; $N M P=1$ methyl-2-pyrrolidinone.

of such catalytic system in reductive couplings is underway in our laboratory.

\section{Methods}

Synthesis of 1a-1f, 1i-11, 3a-3c, 3e, 3i-3l, 3p, 3s, and 3aa. In a $50 \mathrm{~mL}$ threeneck flask equipped with a carbon felt cathode and a $\mathrm{Zn}$ plate, aryl halides (0.3 mmol), $\mathrm{NiBr}_{2} \bullet \operatorname{DME}(0.03 \mathrm{mmol}, 10 \mathrm{~mol} \%), 4,4^{\prime}$-di-tert-butyl-2,2'-bipyridine $(0.03 \mathrm{mmol}, 10 \mathrm{~mol} \%)$, DMAP $(0.06 \mathrm{mmol}, 20 \mathrm{~mol} \%), \mathrm{KO}^{t} \mathrm{Bu}(0.15 \mathrm{mmol}$, 0.5 equiv), anhydrous $\mathrm{MgBr}_{2}$ ( $0.45 \mathrm{mmol}, 1.5$ equiv), $\mathrm{NaI}(1.2 \mathrm{mmol})$ were loaded in the glove box. Then the mixture was taken out of the box, degassed under vacuum, and back-filled with $\mathrm{CO}_{2}$ gas for five times (each time lasted for $1 \mathrm{~min})$. After that, anhydrous NMP $(6 \mathrm{~mL})$ was injected into the flask via a syringe and dissolved the mixture under the strong stirring until the mixture becoming transparent. Then two electrodes were submerged into the solution and conducted under $60^{\circ} \mathrm{C}$. Constant current $(10 \mathrm{~mA})$ was passed until the starting material was consumed. After electrolysis, the mixture was acidized by $2 \mathrm{~N} \mathrm{HCl}$ solution $(20 \mathrm{~mL})$ and extracted by EtOAc for four times $(30 \mathrm{~mL} \times 4)$. The combined organic layers were washed with water $(20 \mathrm{~mL} \times 2)$ and brine $(20 \mathrm{~mL})$ and concentrated in vacuo. Then the residue was purified by silica gel column chromatography by using the petroleum ether/EtOAc to give out the carboxylic acid.
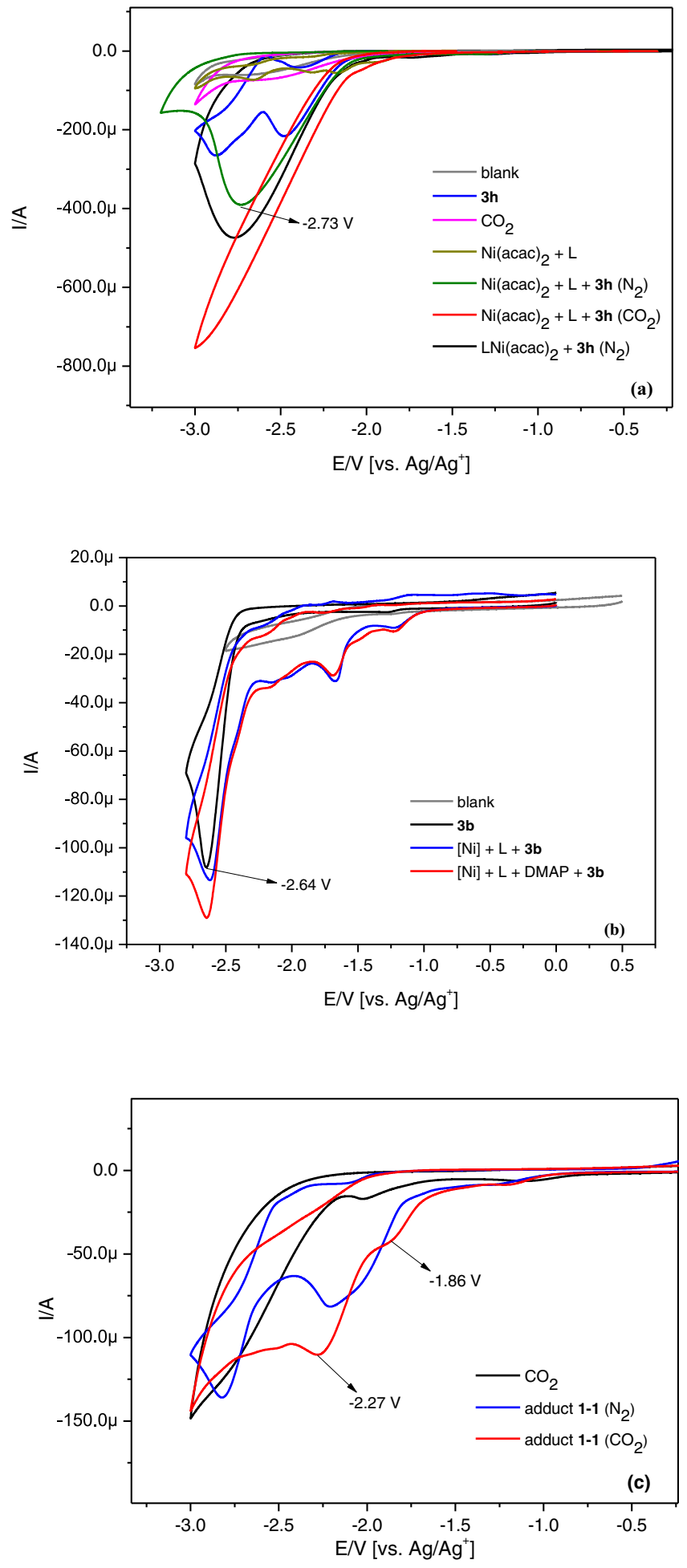

Fig. 7 Performance of nickel catalysts in CV tests. Testing conditions: working electrode, glassy carbon electrode; counter electrode, Pt wire; reference electrode, $\mathrm{Ag} / \mathrm{AgNO}_{3}$ electrode ( $10 \mathrm{mM} \mathrm{AgNO}$ in $\mathrm{CH}_{3} \mathrm{CN}$ ). Scan rate: $100 \mathrm{mV} / \mathrm{s}$. Solvent: $\mathrm{NMP} /{ }^{\mathrm{B} B u_{4}} \mathrm{NPF}_{6}(0.1 \mathrm{M})$. Samples were tested under $\mathrm{N}_{2}$ atmosphere except some cases under $\mathrm{CO}_{2}$ atmosphere. a $\mathrm{CV}$ tests of $\left[\mathrm{Ni}(\mathrm{acac})_{2}+\text { dtbbpy] and aryl bromide } \mathbf{3} \mathbf{h} \text {. Ni(acac }\right)_{2}, 3 \mathrm{mM}$; $\mathrm{L}$, dtbbpy, $3 \mathrm{mM}$; LNi(acac) $2,3 \mathrm{mM}$; $\mathbf{3}$ h, ethyl 4-bromobenzoate, $60 \mathrm{mM}$; $\mathrm{CO}_{2}$ (bubbled in the solution for $10 \mathrm{~min}$ ). $\mathbf{b} \mathrm{CV}$ tests for the role of DMAP. [Ni], $\mathrm{NiBr}_{2}$ (DME), $3 \mathrm{mM}$; L, dtbbpy, 3 mM; DMAP, $3 \mathrm{mM}$, 3b, 4bromophenyl, $5 \mathrm{mM}$. c CV tests of adduct 1-1. adduct 1-1, $5 \mathrm{mM} ; \mathrm{CO}_{2}$ (bubbled in the solution for $10 \mathrm{~min}$ ). L, dtbbpy, 4,4'-di-tert-butyl-2,2'bipyridine; DMAP, 4-dimethylaminopyridine. 


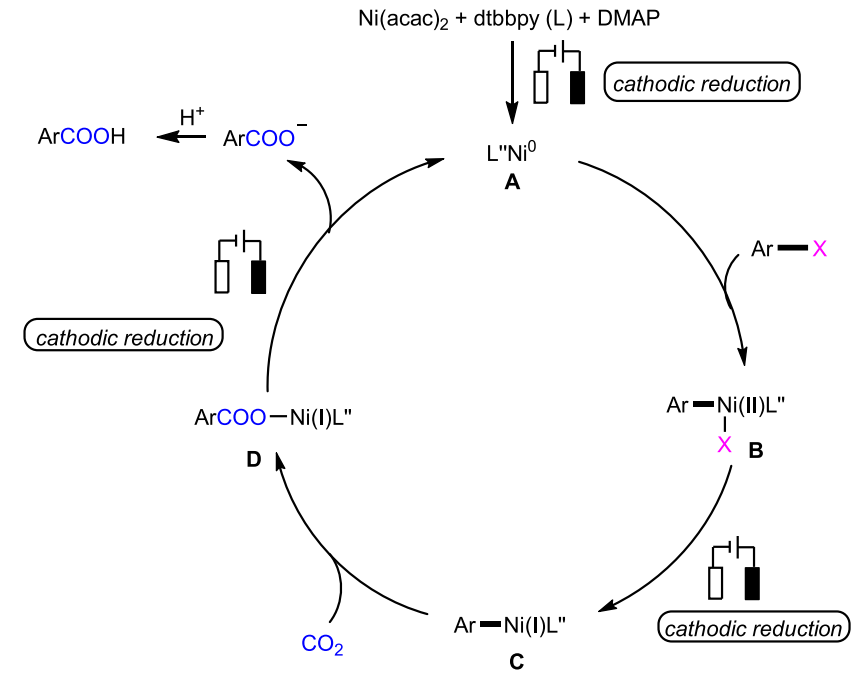

Fig. 8 Proposed mechanistic cycle. Proposed reaction pathway is started up via the electro-generated $\mathrm{Ni}(0)$ species.

Synthesis of 3d, 3f-3h, 3m-30, 3q-3r, 3t-3z and 3ab. In a $50 \mathrm{~mL}$ three-neck flask equipped with a carbon felt cathode and a $\mathrm{Zn}$ plate, aryl halides $(0.3 \mathrm{mmol})$, $\mathrm{Ni}(\mathrm{acac})_{2}(0.015 \mathrm{mmol}, 5 \mathrm{~mol} \%), 4,4^{\prime}$-di-tert-butyl-2,2'-bipyridine $(0.015 \mathrm{mmol}$, $5 \mathrm{~mol} \%), \mathrm{KO}^{t} \mathrm{Bu}(0.15 \mathrm{mmol}, 0.5$ equiv), $\mathrm{NaI}(1.2 \mathrm{mmol})$ were loaded in the glove box. Then the mixture was taken out of the box, degassed under vacuum and backfilled with $\mathrm{CO}_{2}$ gas for five times (each time lasted for $1 \mathrm{~min}$ ). After that, anhydrous NMP $(6 \mathrm{~mL})$ was injected into the flask via a syringe and dissolved the mixture under the strong stirring until the mixture becoming transparent. Then two electrodes were submerged into the solution and conducted under room temperature or $50^{\circ} \mathrm{C}$. Constant current $(8 \mathrm{~mA})$ was passed until the starting material was consumed. After electrolysis, the mixture was acidized by $2 \mathrm{~N} \mathrm{HCl}$ solution $(20 \mathrm{~mL})$ and extracted by EtOAc for four times $(30 \mathrm{~mL} \times 4)$. The combined organic layers were washed with water $(20 \mathrm{~mL} \times 2)$ and brine $(20 \mathrm{~mL})$ and concentrated in vacuo. Then the residue was purified by silica gel column chromatography by using the petroleum ether/EtOAc to give out the carboxylic acid.

Synthesis of 5a-5i. In a $50 \mathrm{~mL}$ three-neck flask equipped with a carbon felt cathode and a $\mathrm{Zn}$ plate, alkyl bromides $(0.5 \mathrm{mmol}), \mathrm{NiBr}_{2} \bullet \mathrm{DME}(0.05 \mathrm{mmol}$, $10 \mathrm{~mol} \%$ ), 6,6'-di-methyl-2,2'-bipyridine ( $0.1 \mathrm{mmol}, 20 \mathrm{~mol} \%)$, CsF $(0.5 \mathrm{mmol}$, 1.0 equiv), $\mathrm{LiClO}_{4}(1.2 \mathrm{mmol})$ were loaded in the glove box. Then the mixture was taken out of the box, degassed under vacuum, and back-filled with $\mathrm{CO}_{2}$ gas for five times (each time lasted for $1 \mathrm{~min})$. After that, anhydrous NMP $(6 \mathrm{~mL})$ was injected into the flask via a syringe and dissolved the mixture under the strong stirring until the mixture becoming transparent. Then two electrodes were submerged into the solution and conducted under room temperature. Constant current (4 or $8 \mathrm{~mA})$ was passed until the starting material was consumed. After electrolysis, the mixture was acidized by $2 \mathrm{~N} \mathrm{HCl}$ solution $(20 \mathrm{~mL})$ and extracted by EtOAc for four times $(30 \mathrm{~mL} \times 4)$. The combined organic layers were washed with water $(20 \mathrm{~mL} \times 2)$ and brine $(20 \mathrm{~mL})$ and concentrated in vacuo. Then the residue was purified by silica gel column chromatography by using the petroleum ether/EtOAc to give out the carboxylic acid.

Synthesis of $3 a-3 b, 3 d-3 f, 3 j-3 k, 3 n-3 s, 3 x-3 y$, and 3aa-3ae (non-sacrificial anode manner). In an $\mathrm{H}$-type divided cell equipped with a carbon felt cathode and a carbon felt anode in each chamber, aryl bromides $(0.3 \mathrm{mmol}), \mathrm{Ni}(\mathrm{acac})_{2}$ (0.03 mmol, $10 \mathrm{~mol} \%$ ), 4,4'-di-tert-butyl-2,2'-bipyridine ( $0.03 \mathrm{mmol}, 10 \mathrm{~mol} \%)$, $\mathrm{KO}^{t} \mathrm{Bu}(0.15 \mathrm{mmol}, 0.5$ equiv), 4 Å molecular sieve $(100 \mathrm{mg}), \mathrm{NaI}(1.2 \mathrm{mmol})$ were loaded in the cathodic chamber. In the anodic chamber, $\mathrm{LiCl}(1.8 \mathrm{mmol})$ was added. Then the reaction vial was taken out of the box, degassed under vacuum, and back-filled with $\mathrm{CO}_{2}$ gas for five times (each time lasted for $1 \mathrm{~min}$ ). After that, anhydrous NMP $(6 \mathrm{~mL})$ was injected into each chamber via a syringe and dissolved the mixture under the strong stirring until the solution becoming transparent. Then dry toluene $(0.6 \mathrm{mmol})$ was injected into anodic chamber via syringe. After that, two electrodes were submerged into the solution. Constant cell voltage $(3 \mathrm{~V})$ was set to the reaction until the starting material was consumed at room temperature. After electrolysis, the mixture of both chambers was acidized by $2 \mathrm{~N} \mathrm{HCl}$ solution $(20 \mathrm{~mL})$ and extracted by EtOAc for four times $(30 \mathrm{~mL} \times 4)$. The combined organic layers were washed with water $(20 \mathrm{~mL} \times 2)$ and saturated $\mathrm{NH}_{4} \mathrm{Cl}$ solution $(20 \mathrm{~mL})$ and concentrated in vacuo. Then the residue was purified by silica gel column chromatography by using petroleum ether/EtOAc to give out the carboxylic acids. Further details may be found in the Supplemental Information.
Synthesis of 1a, 1c, 1e-1g, 1i, and 11-1m (non-sacrificial anode manner). In a $\mathrm{H}$-type divided cell equipped with a carbon felt cathode and a carbon felt anode in each chamber, aryl bromides $(0.3 \mathrm{mmol}), \mathrm{NiI}_{2}(0.03 \mathrm{mmol}, 10 \mathrm{~mol} \%), 4,4^{\prime}$-di-tertbutyl-2,2'-bipyridine ( $0.03 \mathrm{mmol}, 10 \mathrm{~mol} \%)$, DMAP $(0.06 \mathrm{mmol}, 20 \mathrm{~mol} \%), \mathrm{KO}^{t} \mathrm{Bu}$ $(0.15 \mathrm{mmol}, 0.5$ equiv), $\mathrm{NaI}(1.2 \mathrm{mmol})$ were loaded in the cathodic chamber. In the anodic chamber, $\mathrm{NaI}(1.2 \mathrm{mmol})$ was added. Then the reaction vial was taken out of the box, degassed under vacuum, and back-filled with $\mathrm{CO}_{2}$ gas for five times (each time lasted for $1 \mathrm{~min})$. After that, anhydrous NMP $(6 \mathrm{~mL})$ was injected into each chamber via a syringe and dissolved the mixture under the strong stirring until the solution becoming transparent. Then $\mathrm{dry} \mathrm{Et}_{3} \mathrm{~N}(0.6 \mathrm{mmol})$ was injected into anodic chamber via syringe. After that, two electrodes were submerged into the solution. Constant cell voltage $(3 \mathrm{~V})$ was set to the reaction until the starting material was consumed at room temperature. After electrolysis, the mixture of both chambers was acidized by $2 \mathrm{~N} \mathrm{HCl}$ solution $(20 \mathrm{~mL})$ and extracted by EtOAc for four times $(30 \mathrm{~mL} \times 4)$. The combined organic layers were washed with water $(20 \mathrm{~mL} \times 2)$ and saturated $\mathrm{NH}_{4} \mathrm{Cl}$ solution $(20 \mathrm{~mL})$ and concentrated in vacuo. Then the residue was purified by silica gel column chromatography by using petroleum ether/EtOAc to give out the carboxylic acids. Further details may be found in the Supplemental Information.

Synthesis of $\mathbf{5 b} \mathbf{b} \mathbf{5} \mathbf{c}$, and $\mathbf{5 j}$ (non-sacrificial anode manner). In a H-type divided cell equipped with a carbon felt cathode and a carbon felt anode in each chamber, alkyl halide $(0.5 \mathrm{mmol}), \mathrm{NiBr}_{2} \bullet \mathrm{DME}(0.05 \mathrm{mmol}, 10 \mathrm{~mol} \%), 6,6^{\prime}$-di-methyl-2,2'bipyridine ( $0.1 \mathrm{mmol}, 20 \mathrm{~mol} \%), \mathrm{CsF}\left(0.5 \mathrm{mmol}, 1.0\right.$ equiv), $\mathrm{LiClO}_{4}(1.2 \mathrm{mmol})$ were loaded in the cathodic chamber. In the anodic chamber, $\mathrm{LiClO}_{4}(1.2 \mathrm{mmol})$ was added. Then the reaction vial was taken out of the box, degassed under vacuum, and back-filled with $\mathrm{CO}_{2}$ gas for five times (each time lasted for $1 \mathrm{~min}$ ) After that, anhydrous NMP $(6 \mathrm{~mL})$ was injected into each chamber via a syringe and dissolved the mixture under the strong stirring until the solution becoming

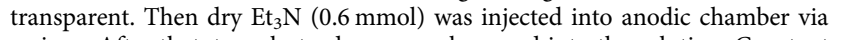
syringe. After that, two electrodes were submerged into the solution. Constant cell voltage $(3 \mathrm{~V})$ was set to the reaction until the starting material was consumed at room temperature. After electrolysis, the mixture of both chambers was acidized by $2 \mathrm{~N} \mathrm{HCl}$ solution $(20 \mathrm{~mL})$ and extracted by EtOAc for four times $(30 \mathrm{~mL} \times 4)$. The combined organic layers were washed with water $(20 \mathrm{~mL} \times 2)$ and saturated $\mathrm{NH}_{4} \mathrm{Cl}$ solution $(20 \mathrm{~mL})$ and concentrated in vacuo. Then the residue was purified by silica gel column chromatography by using petroleum ether/EtOAc to give out the carboxylic acids. Further details may be found in the Supplemental Information.

\section{Data availability}

The authors declare that the data supporting the findings of this study are available within the article and its Supplemental Information files. Extra data are available from the author upon request.

Received: 6 May 2021; Accepted: 18 November 2021; Published online: 06 December 2021

\section{References}

1. Krische M. J. Metal catalyzed reductive $\mathrm{C}-\mathrm{C}$ bond formation (Springer, 2007).

2. Liu, J., Ye, Y., Sessler, J. L. \& Gong, H. Cross-electrophile couplings of activated and sterically hindered halides and alcohol derivatives. Acc. Chem. Res. 53, 1833-1845 (2020).

3. Weix, D. J. Methods and mechanisms for cross-electrophile coupling of Csp2 halides with alkyl electrophiles. Acc. Chem. Res. 48, 1767-1775 (2015).

4. Xia, Q., Dong, J., Song, H. \& Wang, Q. Visible-Light photocatalysis of the ketyl radical coupling reaction. Chem. Eur. J. 25, 2949-2961 (2019).

5. Yan, M., Kawamata, Y. \& Baran, P. S. Synthetic organic electrochemical methods since 2000: on the verge of a renaissance. Chem. Rev. 117, 13230-13319 (2017).

6. Francke, R., Schille, B. \& Roemelt, M. Homogeneously catalyzed electroreduction of carbon dioxide-methods, mechanisms, and catalysts. Chem. Rev. 118, 4631-4701 (2018).

7. Jiang, Y., Xu, K. \& Zeng, C. Use of electrochemistry in the synthesis of heterocyclic structures. Chem. Rev. 118, 4485-4540 (2018).

8. Yuan, Y. \& Lei, A. Electrochemical oxidative cross-coupling with hydrogen evolution reactions. Acc. Chem. Res. 52, 3309-3324 (2019).

9. Xiong, P. \& Xu, H.-C. Chemistry with electrochemically generated N-centered radicals. Acc. Chem. Res. 52, 3339-3350 (2019).

10. Kingston, C. et al. A survival guide for the "electro-curious". Acc. Chem. Res 53, 72-83 (2020).

11. Francke, R. \& Little, R. D. Redox catalysis in organic electrosynthesis: basic principles and recent developments. Chem. Soc. Rev. 43, 2492-2521 (2014).

12. Jing, Q. \& Moeller, K. D. From molecules to molecular surfaces. Exploiting the interplay between organic synthesis and electrochemistry. Acc. Chem. Res. 53, 135-143 (2020). 
13. Wang, F. \& Stahl, S. S. Electrochemical oxidation of organic molecules at lower overpotential: accessing broader functional group compatibility with electron-proton transfer mediators. Acc. Chem. Res. 53, 561-574 (2020).

14. Chang, X., Zhang, Q. \& Guo, C. Asymmetric electrochemical transformations. Angew. Chem. Int. Ed. 59, 12612-12622 (2020).

15. Jutand, A. Contribution of electrochemistry to organometallic catalysis. Chem. Rev. 108, 2300-2347 (2008).

16. Ackermann, L. Metalla-electrocatalyzed C-H activation by earth-abundant $3 \mathrm{~d}$ metals and beyond. Acc. Chem. Res. 53, 84-104 (2020).

17. Jiao, K.-J., Xing, Y.-K., Yang, Q.-L., Qiu, H. \& Mei, T.-S. Site-selective C-H functionalization via synergistic use of electrochemistry and transition metal catalysis. Acc. Chem. Res. 53, 300-310 (2020).

18. Siu, J. C., Fu, N. \& Lin, S. Catalyzing electrosynthesis: a homogeneous electrocatalytic approach to reaction discovery. Acc. Chem. Res. 53, 547-560 (2020).

19. Qiu, Y., Zhu, C., Stangier, M., Struwe, J. \& Ackermann, L. Rhodaelectrocatalyzed C-H and C-C activation. CCS Chem. 3, 1529-1552 (2021).

20. Yakhvarov, D. G., Khusnuriyalova, A. F. \& Sinyashin, O. G. Electrochemical synthesis and properties of organonickel $\sigma$-complexes. Organometallics 33, 4574-4589 (2014).

21. Kumar, G. S. et al. Nickel-catalyzed chain-walking cross-electrophile coupling of alkyl and aryl halides and olefin hydroarylation enabled by electrochemical reduction. Angew. Chem. Int. Ed. 59, 6513-6519 (2020).

22. Cao, Y., He, X., Wang, N., Li, H.-R. \& He, L.-N. Photochemical and electrochemical carbon dioxide utilization with organic compounds. Chin. J. Chem. 36, 644-659 (2018).

23. Jiao, K.-J. et al. Nickel-catalyzed electrochemical reductive relay crosscoupling of alkyl halides to aryl halides. Angew. Chem. Int. Ed. 59, 6520-6524 (2020).

24. Ackermann, L. Transition-metal-catalyzed carboxylation of $\mathrm{C}-\mathrm{H}$ bonds. Angew. Chem. Int. Ed. 50, 3842-3844 (2011).

25. Huang, K., Sun, C.-L. \& Shi, Z.-J. Transition-metal-catalyzed C-C bond formation through the fixation of carbon dioxide. Chem. Soc. Rev. 40, 2435-2452 (2011).

26. He, M., Sun, Y. \& Han, B. Green carbon science: scientific basis for integrating carbon resource processing, utilization, and recycling. Angew. Chem. Int. Ed. 52, 9620-9633 (2013).

27. Liu, Q., Wu, L., Jackstell, R. \& Beller, M. Using carbon dioxide as a building block in organic synthesis. Nat. Commun. 6, 5933 (2015).

28. Burkart, M. D., Hazari, N., Tway, C. L. \& Zeitler, E. L. Opportunities and challenges for catalysis in carbon dioxide utilization. ACS Catal. 9, 7937-7956 (2019).

29. Zhang, L., Li, Z., Takimoto, M. \& Hou, Z. Carboxylation reactions with carbon dioxide using N-heterocyclic carbene-copper catalysts. Chem. Rec. 20, 494-512 (2020).

30. Song, L. et al. $\mathrm{CO}_{2}=\mathrm{CO}+[\mathrm{O}]$ : recent advances in carbonylation of $\mathrm{C}-\mathrm{H}$ bonds with $\mathrm{CO}_{2}$. Chem. Commun. 56, 8355-8367 (2020).

31. Chen, Y.-G. et al. Transition-metal-catalyzed carboxylation of organic halides and their surrogates with carbon dioxide. Synthesis 50, 35-48 (2018).

32. Tortajada, A., Juliá-Hernández, F., Börjesson, M., Moragas, T. \& Martin, R. Transition-metal-catalyzed carboxylation reactions with carbon dioxide. Angew. Chem. Int. Ed. 57, 15948-15982 (2018).

33. Yeung, C. S. Photoredox catalysis as a strategy for $\mathrm{CO}_{2}$ incorporation: direct access to carboxylic acids from a renewable feedstock. Angew. Chem. Int. Ed. 58, 5492-5502 (2019).

34. Ye, J.-H., Ju, T., Huang, H., Liao, L.-L. \& Yu, D.-G. Radical carboxylative cyclizations and carboxylations with $\mathrm{CO}_{2}$. Acc. Chem. Res. 54, 2518-2531 (2021).

35. Cai, B., Cheo, H. W., Liu, T. \& Wu, J. Light-promoted organic transformations utilizing carbon-based gas molecules as feedstocks. Angew. Chem. Int. Ed. 60, 18950-18980 (2021).

36. Zhang, Z. et al. Visible-light-driven catalytic reductive carboxylation with $\mathrm{CO}_{2}$. ACS Catal. 10, 10871-10885 (2020).

37. He, X., Qiu, L.-Q., Wang, W.-J., Chen, K.-H. \& He, L.-N. Photocarboxylation with $\mathrm{CO}_{2}$ : an appealing and sustainable strategy for $\mathrm{CO} 2$ fixation. Green. Chem. 22, 7301-7320 (2020)

38. Fan, Z., Zhang, Z. \& Xi, C. Light-Mediated carboxylation using carbon dioxide. ChemSusChem 13, 6201-6218 (2020).

39. Matthessen, R., Fransaer, J., Binnemans, K. \& De Vos, D. E. Electrocarboxylation: towards sustainable and efficient synthesis of valuable carboxylic acids. Beilstein J. Org. Chem. 10, 2484-2500 (2014).

40. Senboku, H. \& Katayama, A. Electrochemical carboxylation with carbon dioxide. Curr. Opin. Green. Sustain. Chem. 3, 50-54 (2017).

41. Torii, S. et al. $\mathrm{Pd}(0)$-catalyzed electroreductive carboxylation of aryl halides, $\beta$ bromostyrene, and allyl acetates with $\mathrm{CO}_{2}$. Chem. Lett. 15, 169-172 (1986).
42. Jutand, A., Négri, S. \& Mosleh, A. Palladium catalysed electrosynthesis using aryl trifluoromethanesulfonates (triflates). Synthesis of biaryls and aromatic carboxylic acids. J. Chem. Soc. Chem. Commun. 23, 1729-1730 (1992).

43. Jutand, A. \& Négri, S. Activation of aryl and vinyl triflates by palladium and electron transfer - electrosynthesis of aromatic and $\alpha, \beta$-unsaturated carboxylic acids from carbon dioxide. Eur. J. Org. Chem. 1998, 1811-1821 (1998).

44. Medeiros, M. J., Pintaric, C., Olivero, S. \& Dunach, E. Nickel-catalysed electrochemical carboxylation of allylic acetates and carbonates. Electrochim. Acta 56, 4384-4389 (2011).

45. Jiao, K.-J. et al. Palladium-catalyzed reductive electrocarboxylation of allyl esters with carbon dioxide. Org. Chem. Front. 5, 2244-2248 (2018).

46. Sock, O., Troupel, M. \& Perichon, J. Electrosynthesis of carboxylic acids from organic halides and carbon dioxide. Tetrahedron Lett. 26, 1509-1512 (1985)

47. Niu, D.-F. et al. Electrocatalytic carboxylation of aliphatic halides at silver cathode in acetonitrile. Tetrahedron 64, 10517-10520 (2008).

48. Yang, H. P. et al. Platinum/nitrogen-doped carbon/carbon cloth: a bifunctional catalyst for the electrochemical reduction and carboxylation of $\mathrm{CO}_{2}$ with excellent efficiency. Chem. Commun. 54, 4108-4111 (2018).

49. Yang, H. P. et al. A core-shell-structured silver nanowire/nitrogen-doped carbon catalyst for enhanced and multifunctional electrofixation of $\mathrm{CO}_{2}$. ChemSusChem 11, 3905-3910 (2018).

50. Bazzi, S., Le Duc, G., Schulz, E., Gosmini, C. \& Mellah, M. $\mathrm{CO}_{2}$ activation by electrogenerated divalent samarium for aryl halide carboxylation. Org. Biomol. Chem. 17, 8546-8550 (2019).

51. Shi, S.-H., Liang, Y. \& Jiao, N. Electrochemical oxidation induced selective C-C bond cleavage. Chem. Rev. 121, 485-505 (2021).

52. Matthessen, R., Fransaer, J., Binnemans, K. \& De Vos, D. E. Paired electrosynthesis of diacid and diol precursors using dienes and $\mathrm{CO}_{2}$ as the carbon source. ChemElectroChem 2, 73-76 (2015).

53. Yang, D.-T. et al. Direct electrochemical carboxylation of benzylic C-N bonds with carbon dioxide. ACS Catal. 9, 4699-4705 (2019).

54. Alkayal, A. et al. Harnessing applied potential: selective $\beta$-hydrocarboxylation of substituted olefins. J. Am. Chem. Soc. 142, 1780-1785 (2020).

55. Sheta, A. M. et al. Selective $\alpha, \delta$-hydrocarboxylation of conjugated dienes utilizing $\mathrm{CO}_{2}$ and electrosynthesis. Chem. Sci. 11, 9109-9114 (2020).

56. Gao, X.-T. et al. Direct electrochemical defluorinative carboxylation of $a-\mathrm{CF}_{3}$ alkenes with carbon dioxide. Chem. Sci. 11, 10414-10420 (2020).

57. Metzger, A., Bernhardt, S., Manolikakes, G. \& Knochel, P. $\mathrm{MgCl}_{2}$-accelerated addition of functionalized organozinc reagents to aldehydes, ketones, and carbon dioxide. Angew. Chem. Int. Ed. 49, 4665-4668 (2010).

58. Sayyed, F. B. \& Sakaki, S. The crucial roles of $\mathrm{MgCl}_{2}$ as a non-innocent additive in the Ni-catalyzed carboxylation of benzyl halide with $\mathrm{CO}_{2}$. Chem. Commun. 50, 13026-13029 (2014).

59. Fuse, H., Mitsunuma, H. \& Kanai, M. Catalytic acceptorless dehydrogenation of aliphatic alcohols. J. Am. Chem. Soc. 142, 4493-4499 (2020).

60. Yu, D.-G. et al. Direct arylation/alkylation/magnesiation of benzyl alcohols in the presence of Grignard reagents via Ni-, Fe-, or Co-catalyzed $\mathrm{sp}^{3} \mathrm{C}-\mathrm{O}$ bond activation. J. Am. Chem. Soc. 134, 14638-14641 (2012).

61. So, Y. H. Selective chlorination of toluene by anodic oxidation. J. Org. Chem. 50, 5895-5896 (1985)

62. Shields, B. J. \& Doyle, A. G. Direct C(sp3)-H cross coupling enabled by catalytic generation of chlorine radicals. J. Am. Chem. Soc. 138, 12719-12722 (2016).

63. Sayyed, F. B., Tsuji, Y. \& Sakaki, S. The crucial role of a Ni(I) intermediate in $\mathrm{Ni}$-catalyzed carboxylation of aryl chloride with $\mathrm{CO}_{2}$ : a theoretical study. Chem. Commun. 49, 10715-10717 (2013).

64. Diccianni, J. B., Hu, C. T. \& Diao, T. Insertion of $\mathrm{CO}_{2}$ mediated by a (Xantphos)NiI-alkyl species. Angew. Chem. Int. Ed. 58, 13865-13868 (2019).

\section{Acknowledgements}

Financial support is provided by the National Natural Science Foundation of China (21822108), Sichuan Science and Technology Program (20CXTD0112), Fundamental Research Funds from Sichuan University (2020SCUNL102), and the Fundamental Research Funds for the Central Universities. We thank Xiaoyan Wang from the Analysis and Testing Center of Sichuan University for helping us perform NMR studies and the comprehensive training platform of the Specialized Laboratory in the College of Chemistry at Sichuan University for compound testing.

\section{Author contributions}

D.G.Y. and G.Q.S. conceived and designed the study, and wrote the manuscript. G.Q.S., W.Z., L.L.L., L.L., Z.H.N., J.G.W., and Z.Z. performed the experiments, mechanistic studies, and revised the manuscript. All authors contributed to the analysis and interpretation of the data. 


\section{Competing interests}

The authors declare the following competing financial interest(s): A Chinese Patent on this work has been authorized with the number (202010244592.7). The authors declare no other competing interests.

\section{Additional information}

Supplementary information The online version contains supplementary material available at https://doi.org/10.1038/s41467-021-27437-8.

Correspondence and requests for materials should be addressed to Da-Gang Yu.

Peer review information Nature Communications thanks Marta Feroci and the other anonymous, reviewer(s) for their contribution to the peer review of this work.

Reprints and permission information is available at http://www.nature.com/reprints

Publisher's note Springer Nature remains neutral with regard to jurisdictional claims in published maps and institutional affiliations. (c) (i) Open Access This article is licensed under a Creative Commons Attribution 4.0 International License, which permits use, sharing, adaptation, distribution and reproduction in any medium or format, as long as you give appropriate credit to the original author(s) and the source, provide a link to the Creative Commons license, and indicate if changes were made. The images or other third party material in this article are included in the article's Creative Commons license, unless indicated otherwise in a credit line to the material. If material is not included in the article's Creative Commons license and your intended use is not permitted by statutory regulation or exceeds the permitted use, you will need to obtain permission directly from the copyright holder. To view a copy of this license, visit http://creativecommons.org/ licenses/by/4.0/.

(C) The Author(s) 2021 